\title{
Investigation of the Change Towards Scientific Attitudes of Students with Out-of-School Learning Experience
}

\author{
DOI: 10.26466/opus.933305
}

\author{
* \\ $\underline{\text { Arzu Küçük* }}$ \\ * Dr., Ministry of National Education, Rize/Turkey \\ E-Mail: arzukucuk@gmail.com \\ ORCID: $\underline{0000-0001-8933-8179}$
}

\begin{abstract}
The research aimed to follow the long term change of an intervention conducted outside of school for the human and environmental unit in science course on scientific attitude. The research was designed according to a single group pre-post-test simple experimental model. The sample consisted of 21 students studying in the 5th grade of a middle school in Turkey. Both qualitative and quantitative data were collected. Quantitative data were collected with the Scientific Attitude Inventory (SAI II) developed by Moore and Foy (1997). It was applied four times, in the beginning, at the end of the intervention, in the sixth, and also one and the half-year following. Qualitative data were also collected to explain and verify the quantitative results. A total of 13 students were conducted an open-ended questionnaire. SPSS program was used to analyzing the quantitative data and also qualitative data were subject to content analysis. The results of SAI II revealed a statistically significant change in just at the third subscale. Based on the qualitative results, the change in the scientific attitudes of the students was attributed to the fact that they watched the speeches of scientists on communication tools such as television and the internet during their stay at home due to the Covid-19 epidemic, as a reflection of the learning products of the applied program. The fact that a partial decrease and/or increase in the other subscales pointed to the permanence of science teaching outside of school to some extent.
\end{abstract}

Keywords: Scientific Attitude, Out-Of-School Learning, Science Teaching, Long Term Effect. 


\section{Okul Dışı Öğrenme Deneyimi Yaşayan Öğrencilerin Bilimsel Tutumlarındaki Değişimin İncelenmesi}

\section{Öz}

Bu çalışmanın amacl, fen bilimleri dersi insan ve çevre ünitesini okul dışında işleyen öğrencilerin bilimsel tutumlarındaki uzun süreli değişimi incelemektir. Çalışma tek gruplu ön-son test basit deneysel desene göre tasarlanmıştır. Örneklem, ortaokul beşinci sımıfta okuyan 21 öğrenciden oluşmaktadır. Hem nicel hem de nitel veriler toplanmıştır. Nicel veriler Moore ve Foy (1997) tarafından geliştirilen Bilimsel Tutum Envanteri yardımıyla toplanmıştır. Bu araç uygulamanın başında, bitiminde, izleyen altı ve onsekizinci aylarda dört kez uygulanmıştır. Nitel veriler, nicel verileri açılamak için toplanmıştır. Bu amaçla 13 öğrenciyle tek soruluk bir açık uçlu anket yapılmıştır. Nicel veriler SPSS programıyla ve nitel veriler ise içerik analizi yöntemiyle analiz edilmiştir. Bunun sonucunda yalnızca ölçme aracındaki üçüncü alt ölçekte ve son izleme lehine istatistiksel olarak anlamlı bir farklllık ortaya çımıştır. Nitel sonuçlara dayalı olarak öğrencilerin bilimsel tutumlarındaki değişim, uygulanan programın öğrenme ürünlerinin bir yansıması olarak ve Covid-19 salgını nedeniyle evde kaldıkları dönemde televizyon ve internet gibi iletişim araçlarında bilim insanlarının konuşmaların izlemelerine bağlanmıştır. Bununla birlikte diğer alt ölçeklerdeki kısmi artış ve azalış ise açıkça okul dışı fen öğretiminin kalıcıllğına işaret etmektedir.

Anahtar Kelimeler: $\quad$ Bilimsel Tutum, Okul Dışı Öğrenme, Fen Öğretimi, Uzun Süreli Etki. 


\section{Introduction}

In the last two decades, there have been fundamental changes in the aims of science courses. The aims, which are to gain fundamental science knowledge, have been restructured in the form of raising "scientific literate" individuals both in written sources and in the speeches of politicians about education because knowledge increases rapidly and access to it has become easier (Suerdem and Cagliyor, 2016; Yacoubian, 2018). Science education is important in raising science-literate individuals who can use and research scientific process skills, and exhibit positive attitudes towards science (Bybee, 1997; DeBoer, 2000; Cepni, Bacanak, and Kucuk, 2003; Kucuk, Goz, and Kucuk, 2021). Since a child or even an adult cannot have information on every subject, understanding of the scientific authority "how and by which methods can be accessed to the correct information" emerges as a more total and logical solution. Although contrary to popular belief that science needs a culture in which it will flourish in scientific work, science is not a set of formulas and texts produced by gifted people that no one can understand. Societies with a high level of scientific literacy are in a position to lead the changes, as well as keep up with innovations more quickly. World countries have developed and implemented educational programs based on scientific literacy to develop a society with scientific literate (Holbrook and Rannikmae, 2009). Sciencetechnology literacy has left its mark on scientific literacy to a great extent on the reform movements in the field of science education in Turkey (Cepni, Bacanak, and Kucuk, 2003; Derman, 2014). In this context, scientific knowledge, its formation, and development are the product of curiosity, questioning, and thinking people from among the public. For this situation to be understood by the members of the society, it is necessary to plan and carry out teaching-learning practices that can reveal the aforementioned outcomes. In this way, it is possible for all individuals that make up the society to be scientifically literate and contribute to the process.

There are many definitions in the literature on science literacy. It is the most noticeable among these are, "scientific literacy requires being able to use scientific knowledge, understanding the world by identifying problems and producing evidence-based results, and making decisions about 
the changes people cause" (Bybee, 1997) and "developing the ability to creatively utilize sound scientific knowledge in everyday life or in a career, to solve problems, make decisions and hence improve the quality of life" (Holbrook and Rannikmae, 2007). Scientific literacy is an important context in the development of individuals' research, inquiry, and problemsolving skills (Bingham, 1998). Based on both definitions, science literacy means understanding the basic concepts and methods of science enough to use them in daily life and individual decision-making processes and being able to understand and use scientific data. Similarly, it emerges as a complex concept formed not only by knowledge but also by scientific skills, attitudes, and values (Bybee, 1985). Although some measurement tools can show whether a child is science literate or not, it is not possible to fully test this. First of all, it is a need to know the characteristics of individuals who are accepted as scientifically literate. Pella, O'Hearn, and Gale (1966) explained that a scientifically literate individual has some features listed as - knows the relationship and interaction between science and society, - understands the nature of science, - knows the ethical values that scientists abide by, - understands basic ideas in science, - can understand the difference between science and humanities. From this point of view, it would be appropriate to look separately at the subjects related to science literacy and known as its sub-dimensions in the conceptual framework. In the literature, science literacy is defined in four dimensions as scientific knowledge, the investigative nature of science, science that conveys knowledge, and the interaction of science-technology and society (Bou Jaude, 2002; Chiapetta, Sethna, and Fillman, 1993; Lederman and Niess, 1998). The dimension of science that conveys the information contained here focuses on thinking, scrutiny, and reflection in the formation of scientific knowledge and the work of scientists. In this dimension, the intellectual dimension required to create scientific knowledge by doing science is emphasized. Knowing the nature of science and scientific knowledge is also within the scope of this dimension (Lederman and Niess, 1998). Science literacy in the science and technology curriculum, which started to be implemented for the first time in Turkey in 2004 (Bozyılmaz, 2005; Kilic-Bagci, Haymana, and Bozyilmaz, 2008). It was identified as, (i) The nature of science and technology, (ii) Key science concepts, (iii) Scientific 
process skills, (iv) Science-Technology-Society-Environment relationships, (v) Scientific and technical psychomotor skills, (vi) Values that form the essence of science, and (vii) Attitudes and values regarding science.

In this context, the fact that these phenomena, each of which are diagnosed with various tools, are sufficiently high in an individual to be science literate. As an example, being able to have acceptable views on the nature of science alone may reveal some clues, although it is not sufficient to predict science literacy alone (Kucuk, 2006). Scientific attitudes also emerge as the main issue used in the prediction of science literacy (Kucuk and Yildirim, 2020). There are two dimensions of attitude that need to be developed in learning science. The first dimension is the attitude towards science and it refers to an interest in science and technology, environmental awareness, and valuing scientific approaches to inquiry (OECD, 2017). Similarly, in the dimension of attitudes and values regarding the science of scientific literacy, it is emphasized that science-literate individuals should have a positive attitude towards science, love science, and absorb scientific knowledge into their lives (Kucuk, 2021a). Thus, students' scientific attitude is important in determining their motivation and passion to do scientific research and in developing a profound interest to explore the natural phenomena in the universe (Pitaf and Farooq, 2012). For a society with a science culture to be formed, science must first become an important element of the culture of individuals. Basaran (1978) explained scientific attitudes as the ability of the individual to separate the problems, events, and situations they encounter from their feelings as much as possible and interpret them based on the logical data they have. While the mental aspect is predominant in scientific attitudes, the affective aspect is more dominant in attitudes towards science (Hamurcu, 2002). Stephens (1999) grouped seven distinct attitudes towards science at primary and high school level as; the social content of the science, the situations related to the life of scientists, the attitude towards scientific research, the acceptance of scientific attitudes, the pleasure and desire of the science and the lessons, the interest in science and the choice of a profession related to science. Simpson, Koballa Jr, Oliver, and Crawley (1994) also grouped scientific attitudes as, (i) willingness to understand and know, (ii) willing to question everything, (iii) to collect data and search for its meaning, (iv) 
desire to prove its accuracy, (v) respect for logic (vi) thinking of premises and (vii) thinking of conclusions.

It is effective to have these attitudes in the emergence of many other learning products directly and/or indirectly, such as to research, question, think critically, stay away from prejudices and dogmatic belief systems, to know and solve the problems in the environment and to seek solutions for this, to apply the solution by believing, however, to appreciate the opinions of those who will criticize the solution and academically and also being successful (Kucuk, 2006). Students who have acquired scientific attitudes may have an increase in their attitudes towards science (Kursad, 2015; Yavuz Topaloglu and Balcin, 2021). In this case, the question is which teaching approaches, methods and techniques and even learning environments will focus on the goal of achieving science literacy by enriching scientific attitudes. It is expected that cognitive and affective dimensions are taken into account in developing scientific attitudes and instruction is planned accordingly.

There is a plenty of work on how scientific attitudes can be better structured in informal learning environments rather than formal learning environments, including school-based field trips to also scientific institutions (Anderson, Lucas, and Ginns, 2003; Ash, 2003; Behrent and Franklin, 2014; Bulbul and Degirmencay, 2021; Griffin, 2004; Lin and Schunn, 2016, Kucuk and Yildirim, 2020; Ozturk, 2014). This type of field trip can be used for scientific research through multiple experiences offered to students in authentic settings (Bakioglu and Karamustafaoglu, 2014; Knapp, 2000; Kucuk, 2020; Walan and Gericke, 2019). Both the process and the nature of the enterprise can be learned. The quality of these experiences can also encourage students to learn deeply about the subject presented and to increase their interest in science. In this context, within the scope of field trips, conferences, interviews, panels, etc. given by scientists on subjects that are up-to-date for children (Kucuk and Yildirim, 2021). It is an important issue in the formation of scientific attitudes to enable them to participate in activities and to provide them with the opportunities to communicate with them. It is also an important need to convey the topics to be presented in this communication process by the relevant scientists in a popular language and to provide answers to the questions posed by the students in a way that is appropriate to their level and that can encourage 
the inquiry processes (Kucuk, 2020). This process is also marked by children abandoning stereotypical images of scientists. A correct scientist is also an important opportunity in terms of structuring the images.

Informal learning or the concept of learning outside of school and classroom, which is included in the literature with different definitions and names in the subject field, contributes to the content and gains of the course made outside the physical, psychological, and even sociological walls of the school in the most general sense (Kucuk, 2020). In one of these, out-of-school activities are defined as, "the activities planned, scheduled and regular work done at school or outside of school by the purposes of education, in line with the interests and wishes of the students, under the knowledge of the school management and under the guidance of the teacher to develop their personalities" (Binbasioglu, 2000). In another, outof-school learning is defined as the activities performed more directed towards achievements in science teaching by examining an event or phenomenon in its real natural environment according to the plan made (Rickinson, et al., 2004). Non-formal learning environments; support students' learning environments that provide an opportunity for their configuration. Informal learning is a positive attitude that allows them to gain experience, provides permanent knowledge (Kelly, 2000; Martin, 2004). It includes many social areas that allow it to develop. Among these environments, museums, zoos, botanical gardens, science centers, nature areas, etc. (Hofstein and Rosenfeld, 1996). Eschenhagen, Katmann, and Rodi (2008) suggested that school gardens, agriculture all nature near the school, such as nature protection (National Park) areas can be used as an out-of-school learning environment. However, revealing the achievements of the curriculum school-based field trips to public institutions and organizations with an interactive exhibition, panel, theater, etc. areas as out-of-school learning environments are available (Kucuk, 2020). Such centers, through the students' personal experience of events and phenomena, and by interacting with real object materials the can enable them to achieve gains of the important cognitive, affective and psychomotor domains (Salmi, 1993). Most importantly, out-of-school learning environments greatly increase and enrich children's interest and motivation for learning (Andiema, 2016; Soysal, 2019; Tas and Gulen, 2019). It turns out that by out-of-school activities that enrich learning environments in the 
context students can reach the result by collecting data, explore various scientific topics where science skills can improve academic achievements and attitudes towards science, increase their interest and curiosity towards science, and establish closer relationships through observation between what is learned in school and real-life (Balkan Kiyici and Atabek Yigit, 2010; Bozdoğan, 2007; Kucuk and Yildirim, 2021).

It can be used effectively in providing scientific attitudes and therefore science literacy (Kucuk and Yildirim, 2020; Walan and Gericke, 2019). In the literature on the subject, it is possible to find some other research supporting this result frequently (Basdag, 2006; Cebi, 2018; Soysal, 2019; Yildirim, 2018). In these studies, the effects of short-term intervention programs such as one-day, weekly, or monthly on scientific attitudes have been tried to be measured (Prokop, Tuncer, and Kvasnicak, 2007). Although it can be concluded that short-term programs can produce somewhat successful outcomes, the main issue is that whether long-term outcomes can produce similar results. It may be possible to eliminate the gap in the subject area, on the one hand, measuring the long-term effects of some programs carried out. Examining how possible scientific attitudes are affected by time can also serve as an important source for suggesting functional new ways of content design for relevant studies in the subject area. On the other hand, considering that students could never go to schools during this period due to the Covid-19 epidemic from March 2020, the research is important in terms of establishing a relationship between a possible change in scientific attitudes and leaving school. Until September 2021, all courses are taught by distance education. In this context, students do not have any formal life where they can experience guided research and investigation activities first hand. However, television programs aimed at combating and preventing the Covid-19 outbreak have been made frequently. Many scientists, mostly professors, host these programs every evening. In short, science and scientific initiatives have entered our lives through these programs as never before in history (Kucuk, 2021b).

The current study focused on the results of the intervention made entirely outside of school for the human and environmental unit in the science course. In this way, approximately one and a half years after the end of the intervention, the change in the scientific attitudes of the program 
participants was examined. In this respect, the research question of the study was formed as follows:

Has there been any change in the scientific attitudes of students who taught the science 5th grade human and environmental unit entirely outside of school?

\section{Method}

In this research, the long-term effects of out-of-school learning environments on the research group's scientific attitudes were investigated. For this purpose, the research was designed according to a single group pretest-post-test simple experimental design model within the scope of the quantitative research approach. In this design, its effect on the process is tested with a study on a single group, and there is no randomness and matching. For this purpose, Scientific Attitude Inventory, (SAI II) was applied four times, in the beginning, at the end of the intervention, in the sixth, and also one and the half-year following. The scientific attitude scores that emerged after the intervention performed on the research group and detailed in the following pages had already been recorded by Kucuk (2020). In the current research, the relationship between the SAI II scores for the first and last follow up which can be considered longer, was examined.

\section{Sample}

The study group of this research consisted of 21 students studying in the 5th grade of a middle school in Cayeli District of Rize, in Turkey. 7 of these students are boys and 14 are girls. Official permissions were obtained from the Rize Provincial Directorate of National Education after obtaining written consent from the parents to carry out this study in the middle school. The attitude scores of the students measured pre and post-intervention and also at the first follow-up reported by Kucuk (2020) are included in table 1. 
Table 1. Distribution of SAI-II scores of the experimental intervention

\begin{tabular}{|c|c|c|c|c|c|c|}
\hline Subscales & Range & Test Time & Min & Max & $X$ & $\mathrm{~s}$ \\
\hline \multirow[t]{4}{*}{ Subscale 1} & $6-30$ & Pre-intervention & 16,00 & 23,00 & 19,04 & 1,85 \\
\hline & & Post-intervention & 17,00 & 24,00 & 19,61 & 1,96 \\
\hline & & First follow-up & 13,00 & 24,00 & 19,71 & 2,75 \\
\hline & $6-30$ & Pre-intervention & 19,00 & 30,00 & 24,90 & 2,80 \\
\hline \multirow[t]{2}{*}{ Subscale 2} & & Post-intervention & 20,00 & 29,00 & 24,71 & 2,45 \\
\hline & & First follow-up & 20,00 & 30,00 & 24,47 & 2,56 \\
\hline \multirow[t]{4}{*}{ Subscale 3} & $6-30$ & Pre-intervention & 18,00 & 30,00 & 22,90 & 3,23 \\
\hline & & Post-intervention & 17,00 & 29,00 & 23,28 & 3,22 \\
\hline & & First follow-up & 19,00 & 29,00 & 23,00 & 2,73 \\
\hline & $6-30$ & Pre-intervention & 13,00 & 24,00 & 19,09 & 2,73 \\
\hline \multirow[t]{2}{*}{ Subscale 4} & & Post-intervention & 17,00 & 23,00 & 19,23 & 1,48 \\
\hline & & First follow-up & 13,00 & 21,00 & 18,57 & 1,83 \\
\hline \multirow[t]{4}{*}{ Subscale 5} & $6-30$ & Pre-intervention & 15,00 & 28,00 & 21,66 & 3,75 \\
\hline & & Post-intervention & 13,00 & 30,00 & 23,23 & 3,91 \\
\hline & & First follow-up & 17,00 & 29,00 & 23,23 & 3,22 \\
\hline & $10-50$ & Pre-intervention & 29,00 & 47,00 & 38,33 & 4,68 \\
\hline \multirow[t]{2}{*}{ Subscale 6} & & Post-intervention & 30,00 & 46,00 & 38,23 & 4,94 \\
\hline & & First follow-up & 33,00 & 48,00 & 39,47 & 4,24 \\
\hline \multirow[t]{3}{*}{ Total } & $40-200$ & Pre-intervention & 121,00 & 165,00 & 145,95 & 10,12 \\
\hline & & Post-intervention & 122,00 & 167,00 & 148,33 & 10,02 \\
\hline & & First follow-up & 135,00 & 158,00 & 148,47 & 6,32 \\
\hline
\end{tabular}

Based on this table, although there were small score changes reflected in the average values among the test scores obtained in the pre, post, and also first follow-up there was no statistically significant difference in the score (Kucuk, 2020). Therefore, an answer to the research question was sought by comparing the first and the second follow-up scores in the results.

\section{The Intervention}

The intervention was made on the subject of the 5th grade Human and Environmental Unit. This unit is included both in the 4th and 5th-grade curriculum in the 2018 Science Course Curriculum (MEB, 2018). It consisted of eight achievements for the 5th-grade. It is aimed to question the causes and consequences of environmental problems, biodiversity, endangered and endangered creatures and the things to be done to protect these species, sensitivity to environmental problems caused by human activities, and to gain knowledge and skills to solve these problems (MEB, 2018). There are three sub-titles as Biodiversity, Human and Environment Relationship, and Destructive Nature Events in it. 
In this research, visits to out-of-school learning environments consisted of three phases: (i) things to do before going to the out-of-school learning environment, (ii) things to do during out-of-school learning environments, and (iii) things to do after returning from out-of-school learning environments by used in other studies (Bakioglu, 2017; Can, 2019). In these three stages, the "structuring", "restructuring" and "reflecting" components of the constructivist theory are properly reflected. What is done in each of these stages was explained in detail by Kucuk (2020). In this context, only short explanations describing the intervention made were included here.

For each out-of-school visit, a worksheet consisted of four parts has been prepared. The first two parts (first is what I know and second is what I want to learn) included brief information about the out-of-school learning environment to be visited and some visuals. The first two pages of outof-school learning worksheets were provided at least one day before going to out-of-school learning environments for students to prepare at home. They are motivated by preparing questions for the second part beforehand, and their interest and curiosity. Preparations made by students before the visit were reviewed in the classroom and/or school. Those were checked by the teacher for the first time in the school garden, the purpose, duration, content of the visit was explained. These first two parts were used as the "structuring" component of the constructivist approach.

To ensure sustainability, the last two parts were provided with the secretary file were to facilitate writing. They used the third page (My Visiting Notes) of the worksheet to take notes and also record their observations during visits. They asked their questions prepared before or recently to the presenter and recorded their answers to think on and also share with the class when turning back. The teacher summed up the subject referring to what they know and what they want to learn after the visit. In this process, students shared their answers to the questions with the class. This stage is used as the component of "restructuring" of the constructivist approach. Finally, students were asked to write short articles, prepare posters, design posters, etc. as extra work individually or in a group to complete at home. These materials were also presented in the classroom. They 
used the fourth page (What I Learned) of the worksheet to think and reflect on all the learning experiences at home. The last stage was used as the "reflection" component of the constructivist approach.

In the school where this research was conducted, full-time education is provided. The practices were conducted by the spring term of 2019. Practices were made mostly by taking the other and/or empty lessons, especially during the science course hours included in the formal timetable, either completely during the school period or partially overflowing the time. The topics, concepts, achievements in the program, durations, activity names, and locations of the intervention program, which lasted for a total of twenty hours, are explained in detail in table 2.

Table 2. Human and environment unit achievements, out-of-school environments, and teaching methods used.

\begin{tabular}{|c|c|c|c|c|c|}
\hline Topics & Topic / Concepts & $\begin{array}{l}\text { Time } \\
\text { (min) }\end{array}$ & Achievements & $\begin{array}{l}\text { Out-of- } \\
\text { School } \\
\text { Environ- } \\
\text { ments }\end{array}$ & $\begin{array}{l}\text { Teach- } \\
\text { ing } \\
\text { Meth- } \\
\text { ods }\end{array}$ \\
\hline \multirow[t]{3}{*}{$\begin{array}{l}\text { Biodiver- } \\
\text { sity }\end{array}$} & \multirow[t]{3}{*}{$\begin{array}{l}\text { Biodiversity, natural } \\
\text { life, extinct crea- } \\
\text { tures, habitat, eco- } \\
\text { system }\end{array}$} & 80 & $\begin{array}{l}\text { F.5.6.1.1.Questions the importance } \\
\text { of biodiversity for natural life. } \\
\text { It gives examples of plants and ani- } \\
\text { mals that are extinct or in danger of } \\
\text { extinction in our country and the } \\
\text { world. }\end{array}$ & $\begin{array}{l}\text { Natural } \\
\text { habitat } \\
\text { Faculty of } \\
\text { Education } \\
\text { Garden }\end{array}$ & $\begin{array}{l}\text { Field } \\
\text { Work, } \\
\text { Game } \\
\text { Orient- } \\
\text { eering }\end{array}$ \\
\hline & & 40 & $\begin{array}{l}\text { F.5.6.1.2. Discusses the factors } \\
\text { threatening biodiversity based on } \\
\text { research data. }\end{array}$ & $\begin{array}{l}\text { Com- } \\
\text { puter Lab }\end{array}$ & $\begin{array}{l}\text { Re- } \\
\text { search } \\
\text { and in- } \\
\text { vesti- } \\
\text { gation }\end{array}$ \\
\hline & & 80 & & $\begin{array}{l}\text { Audito- } \\
\text { rium }\end{array}$ & Panel \\
\hline \multirow{4}{*}{$\begin{array}{l}\text { Human } \\
\text { and En- } \\
\text { viron- } \\
\text { ment Re- } \\
\text { lation- } \\
\text { ship }\end{array}$} & \multirow{4}{*}{$\begin{array}{l}\text { Environmental pol- } \\
\text { lution, environmen- } \\
\text { tal protection, and } \\
\text { beautification, hu- } \\
\text { man-environment } \\
\text { interaction (human } \\
\text { impact on the envi- } \\
\text { ronment), local and } \\
\text { global environmen- } \\
\text { tal problems }\end{array}$} & 40 & $\begin{array}{l}\text { F.5.6.2.1. Express the importance } \\
\text { of the interaction between humans }\end{array}$ & $\begin{array}{l}\text { Theater } \\
\text { Hall }\end{array}$ & Theater \\
\hline & & 60 & $\begin{array}{l}\text { and the environment. } \\
\text { The negative effects of environmental } \\
\text { pollution on people's health are men- } \\
\text { tioned. }\end{array}$ & $\begin{array}{l}\text { Hydroe- } \\
\text { lectric } \\
\text { power } \\
\text { plant }\end{array}$ & $\begin{array}{l}\text { Field } \\
\text { Work, } \\
\text { Semi- } \\
\text { nar }\end{array}$ \\
\hline & & 60 & $\begin{array}{l}\text { the solution of an environmental } \\
\text { problem in its immediate environ- } \\
\text { ment or our country. } \\
\text { F.5.6.2.3. It makes inferences about } \\
\text { environmental problems that may }\end{array}$ & $\begin{array}{l}\text { Airport } \\
\text { Construc- } \\
\text { tion Area }\end{array}$ & $\begin{array}{l}\text { Field } \\
\text { Work, } \\
\text { Semi- } \\
\text { nar }\end{array}$ \\
\hline & & 40 & $\begin{array}{l}\text { occur in the future as a result of } \\
\text { human activities. } \\
\text { F.5.6.2.4. Discusses the examples } \\
\text { of benefits and harms in human- }\end{array}$ & $\begin{array}{l}\text { Univer- } \\
\text { sity Phys- } \\
\text { ics De- } \\
\text { partment }\end{array}$ & $\begin{array}{l}\text { Semi- } \\
\text { nar }\end{array}$ \\
\hline
\end{tabular}




\begin{tabular}{|c|c|c|c|c|c|}
\hline & & 40 & $\begin{array}{l}\text { environment interaction on exam- } \\
\text { ples. }\end{array}$ & $\begin{array}{l}\text { Environ- } \\
\text { ment and } \\
\text { Urbaniza- } \\
\text { tion Rize } \\
\text { Provincial } \\
\text { Direc- } \\
\text { torate }\end{array}$ & $\begin{array}{l}\text { Semi- } \\
\text { nar }\end{array}$ \\
\hline & & 40 & & $\begin{array}{l}\text { Çayeli } \\
\text { District } \\
\text { Health } \\
\text { Direc- } \\
\text { torate }\end{array}$ & $\begin{array}{l}\text { Semi- } \\
\text { nar }\end{array}$ \\
\hline & & 80 & & $\begin{array}{l}\text { Çayeli } \\
\text { District } \\
\text { Center }\end{array}$ & $\begin{array}{l}\text { Re- } \\
\text { search } \\
\text { and in- } \\
\text { vesti- } \\
\text { gation }\end{array}$ \\
\hline $\begin{array}{l}\text { Destruc- } \\
\text { tive Nat- } \\
\text { ural Phe- } \\
\text { nomena }\end{array}$ & $\begin{array}{l}\text { Destructive natural } \\
\text { phenomena and } \\
\text { ways of protection }\end{array}$ & 160 & $\begin{array}{l}\text { F.5.6.3.1. Explains destructive nat- } \\
\text { ural events caused by natural pro- } \\
\text { cesses. } \\
\text { Earthquakes, volcanic eruptions, } \\
\text { floods, landslides, tornadoes, hurri- } \\
\text { canes are mentioned without going } \\
\text { into detail. } \\
\text { F.5.6.3.2. It expresses ways of pro- } \\
\text { tection from destructive natural } \\
\text { events. }\end{array}$ & $\begin{array}{l}\text { Show- } \\
\text { room }\end{array}$ & $\begin{array}{l}\text { Exhibi- } \\
\text { tion }\end{array}$ \\
\hline
\end{tabular}

*This table was retrieved from the research done by Kucuk and Yildirim (2020).

\section{Data Collection}

Both qualitative and quantitative data were collected in this study. Quantitative data of this study were collected with the Scientific Attitude Inventory (SAI II) developed by (Moore and Foy, 1997). This scale includes status statements about science, scientists, and scientific methods, as well as attitudes such as participating in studies related to science, liking or disliking the studies. There are a total of 40 items in the scientific attitude scale, adapted to Turkish by (Demirbas and Yagbasan, 2006). The 40 items in the scale were structured to explain the nature of science, the way scientists work, and how students feel about science. The items are formed in five-point Likert type and the degree of people's participation in the items. It is categorized as "Strongly Agree", "Agree", "Undecided", "Disagree" and "Strongly Disagree". Half of the items on the scale were determined to be positive. In addition, the scale is divided into six - five of the subscales are related to the nature of science and the way scientists work, 
one is included items about how students feel about science - subscales. The Cronbach Alpha reliability coefficient was found to be $.76(\alpha=.76)$. This scale was applied to students after the intervention and one and a half years later. The first application was done face-to-face in the classroom by the researcher, and the next was carried out simultaneously online due to the Covid-19 epidemic. The scores obtained in this way were compared based on total and subscale. However, qualitative data were collected to explain and verify the quantitative results within the scope of the research question. For this purpose, as a result of the analysis, the total 13 students who had 25 or more points from the third sub-scale differed statistically from the scientific attitude scale and in favor of the last followup, were conducted an open-ended questionnaire (In short, write a short text explaining what or what might have changed (if so) your ideas about science, scientific work and especially scientists during this period of distance education in schools for about a year due to the Covid-19 epidemic and therefore staying at home).

\section{Data Analysis}

Statistical analysis to be made on a data set, change according to the type of data obtained in line with its purpose/hypotheses (Buyukozturk, 2016). In the analysis of data, to use parametric tests, data should be obtained at the level of intermittent or proportional scale, the data should be normally distributed, and the assumptions that the variances of the compared samples are homogeneous when two or more samples are compared (Garson, 2012). However, it is stated that the number of data is 30 or more may be suitable for parametric analysis (Field, 2013). In this study, the number of data/samples used in comparisons is below 30. In this context, both the whole subscale and the total scientific attitude scores meet the normality criteria and parametric tests were used. The type of variables and the number of measurements are also determinants in deciding which tests will be used in the analysis. There is only one experimental group in this study. For this reason, the Paired Samples T-Test which is one of the parametric for paired comparisons of first and last follow-up scores of the SAI II was used. This technique tests whether the mean scores of two related sets of measurements differ significantly from each other (Buyukozturk, 
2016). SPSS 24.0 (Statistical Packet for Social Sciences) was used to analyzing the quantitative data, and descriptive statistics. The level of significance has been taken as .05 in all analyzes conducted throughout the research.

The data from the open-ended question was subject to content analysis, coded, and separated into appropriate categories. The main purpose of the content analysis is to reach concepts and relations that can explain the data collected. The other coder, a professor in science education was consulted for the reliability study regarding codes of qualitative research. The researcher and coder also checked the content validity of the open-ended question, and the online form was made final after necessary feedback. In cases when multiple researchers work together in data analysis, a study should be conducted on intercoder reliability. In this case, the researchers code the same set of data and reach a coding percentage by numerically comparing the similarities and differences of coding (Patton, 2018). Intercoder reliability was determined by the researcher and the other coder by independently coding the records. A consensus was reached on all codes. The situation was also described by making direct quotations from the participants' opinions.

\section{Results}

The quantitative and qualitative results were presented under subheadings.

The quantitative results: First of all, the results of the SAI II in the following sixth (introduced as the first follow-up) and eighteenth months (introduced as the last follow-up) are shown in Table 3.

Table 3. The descriptive statistics of SAI-II

\begin{tabular}{llllll}
\hline & & X & N & s & Std. Error Mean \\
\hline Subscale 1 & First follow-up & 19,7143 & 21 & 2,75940 &, 60215 \\
& Last follow-up & 21,0952 & 21 & 2,11907 &, 46242 \\
Subscale 2 & First follow-up & 24,4762 & 21 & 2,56162 &, 55899 \\
& Last follow-up & 24,1429 & 21 & 2,63222 &, 57440 \\
Subscale 3 & First follow-up & 23,0000 & 21 & 2,73861 &, 59761 \\
& Last follow-up & 25,0000 & 21 & 2,38747 &, 52099 \\
Subscale 44 4 & First follow-up & 18,5714 & 21 & 1,83225 &, 39983 \\
& Last follow-up & 19,4286 & 21 & 2,13475 &, 46584
\end{tabular}




\begin{tabular}{llllll} 
Subscale 5 & First follow-up & 23,2381 & 21 & 3,22343 &, 70341 \\
& Last follow-up & 23,1905 & 21 & 3,09223 &, 67478 \\
Subscale 6 & First follow-up & 39,4762 & 21 & 4,24993 &, 92741 \\
& Last follow-up & 36,6190 & 21 & 5,52699 & 1,20609 \\
\multirow{2}{*}{ Total } & First follow-up & 148,4762 & 21 & 6,32945 & 1,38120 \\
& Last follow-up & 149,4762 & 21 & 8,82394 & 1,92554 \\
\hline
\end{tabular}

Based on this table, after the intervention and at the first follow-up SAI II score averages of the participants were $X=19,71$ and it increased to 21,09 at the last follow-up for the first factor (The Structure of Scientific Laws and Theories) of SAI II. Similarly, they were $X=23,00$ and it increased to 25,00 at the last follow-up for the third factor (Scientific Behavior Display) of SAI II and were also X=18,57 and it increased to 19,42 at the last followup for the fourth factor (The Structure and Purpose of Science) of SAI II. Total SAI II test scores also increased from $X=148,4$ to $X=149,477$ at the last follow-up.

However, it decreased from $X=24,4$ in the first follow-up to $X=24,14$ in the last follow-up for the second factor (Structure of Science and Approach to Events), and decreased from $X=23,23$ in the first follow-up to $X=23,19$ in the last follow-up for the fifth factor (The Place and Importance of Science in Society) and also decreased from $X=39,47$ in the first follow-up to $X=36,61$ in the last follow-up for the sixth factor (Willingness to Conduct Scientific Studies).

On the other hand, looking at the standard deviations of the first and last follow-up scores for the subscales, it was found that the deviation decreased in the subscales with score increases in favor of the last follow-up (see the first and third subscales), whereas the deviation increased in the subscales with score decreases (see the fifth and sixth subscales). In the scientific attitude subscales, it is a fact that while attitude scores are increasing, students started to be homogenization and while attitude scores decrease they started to be heterogeneous.

To find an answer to the research question of this study, the first and the second follow-up scores of SAI II were compared. The results are seen in table 4 in terms of subscales and also total score. 
Table 4. Paired Samples Test results of first and second follow-up scores of the SAI II

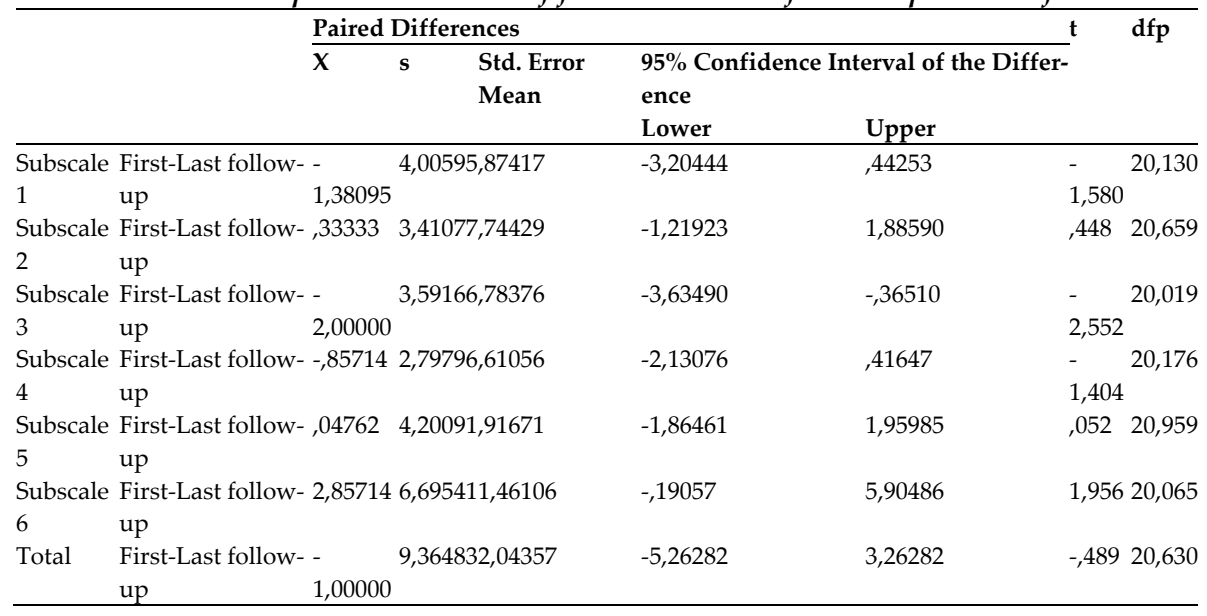

Based on this table, a statistically significant relationship [ $t(20)=-2,55$, $\mathrm{p}<.05]$ was found only in the third subscale (Scientific Behavior Display) as a result of the paired-sample t-test between the first and last follow-up scores of SAI-II. For this subscale, the first follow-up scores of the students were $X=23$, while it increased to $X=25.0$ in the last follow-up. This finding means that students' scientific behavior scores increased in this one-year period, which also coincided with the Covid-19 epidemic.

\section{The qualitative results}

To explain the possible reasons for the high scores recorded in the last follow-up of SAI II, the analysis of the survey data was presented in table 5.

Table 5. Content analysis of the survey data

\begin{tabular}{|c|c|c|}
\hline Theme & Code & Frequency \\
\hline \multirow[t]{5}{*}{$\begin{array}{l}\text { Closely monitoring scientists' work } \\
\text { on vaccine development }\end{array}$} & $\begin{array}{l}\text { See the difficult side of scientific re- } \\
\text { search }\end{array}$ & 4 \\
\hline & $\begin{array}{l}\text { Following news from communica- } \\
\text { tion channels such as TV and the in- } \\
\text { ternet }\end{array}$ & 3 \\
\hline & $\begin{array}{l}\text { Respect and interest in Covid vac- } \\
\text { cine studies }\end{array}$ & 2 \\
\hline & $\begin{array}{l}\text { Increased interest in science-specific } \\
\text { vaccination studies }\end{array}$ & \\
\hline & $\begin{array}{l}\text { Scientists make sacrifices for vac- } \\
\text { cination studies }\end{array}$ & 1 \\
\hline
\end{tabular}




\begin{tabular}{lll} 
& $\begin{array}{l}\text { The epidemic makes it difficult for } \\
\text { scientists to collaborate }\end{array}$ & 1 \\
$\begin{array}{l}\text { More opportunities to read about } \\
\text { science }\end{array}$ & $\begin{array}{l}\text { There are more opportunities to } \\
\text { read about scientific books }\end{array}$ & 2 \\
No change & $\begin{array}{l}\text { Distance education made science } \\
\text { not fun } \\
\text { No change }\end{array}$ & 1 \\
\hline
\end{tabular}

Based on the codes produced in this table, it is revealed that the students who had high scores from the related subscale of the SAI II have followed scientists within the scope of Covid-19 vaccine through different communication channels like TV and/or the internet. It is also important that they refer to the difficulties of the profession and their great sacrifices for humanity and that they respect them. This result indicates that the behaviors of scientists, which are followed and deemed valuable for the benefit of humanity, increase students' attitudes towards scientific behavior.

Below are excerpts from the answers of the students whose subscale scores differed statistically in favor of their final follow-up scores. The total scores of the students calculated from the third subscale with a maximum of thirty points are added to the end of the quotations.

First of all, science, scientific study, scientist, these are really good things and I want to be a scientist, but the Covid 19 outbreak affects scientists to a great extent, and this is bad, they can sacrifice their lives for other people (for example, to find the vaccine). It is indeed a great sacrifice, but I still want to be a scientist. Because then you become like the hero of the people. But of course, I do not want to be a scientist to be a hero. I want to be a scientist because I love science and scientific studies (28 points)

Due to the Covid-19 outbreak, we started to see more scientific studies on TV, on the internet, and in many other places (For example, due to vaccine trials). This process enabled us to see the difficult side of scientists' professions more easily. For this reason, many people, including myself, have changed more or less in their views of the profession (28 points)

The research we have done on this epidemic period through the media and the internet to protect our health may have caused some changes in our ideas. There was a social media during this time and we closed home, we obtained different opinions from many people about the news on this issue and this may have led to changes... this is a global epidemic and it is different if we think that it affects the whole world. We also learned the opinions of people with different cultures on this 
subject... The fact that we lived through this process rather than just watching it from a movie necessarily had an impact on our ideas.... (26 points)

Regarding scientists, studies related to vaccines changed my mind about vaccination. About science, science is already at the top of everything. Without science, we could not even come to the situation we are in now (26 points)

I showed more respect to scientists and scientific studies because they did a lot of drug trials for us. The more I thought about it, the more I realized that the scientists' job was very difficult (25 points)

\section{Discussion}

In the 21st century, when science and technology reached the peak of all times, new information is increasing exponentially in a short period. For this high storage, new virtual areas are formed, including internet and cloud technologies. The information in question, which can be easily accessed when desired, does not need to be stored in the human mind again. For these reasons, there are important changes like formal learning and teaching activities in schools (Karakaya-Akcadag and Omca-Cobanoglu, 2018). Instead of memorizing scientific information in a way that includes science lessons, children should learn the attitudes and mental process skills they will need to solve the problems they may encounter in different periods of their lives (Kucuk, 2021a; Tezel and Tezgoren, 2019).

In this process, it is important to need students to gain a scientific attitude and behave a scientist to approach events like scientists, to question, to think critically, and to learn the nature of scientific knowledge in this way (Kucuk and Bag, 2018). This subject is briefly conceptualized as raising science-literate individuals. Scientific attitudes are among the components of literacy (Koballa Jr and Glynn, 2007). In this context, numerous researchers have investigated the attitudes towards science and also science courses in context to science education (Ali, Akhtar, and Arshad, 2019; Cavus, Oztuna Kaplan, Sunbul, and Cetin, 2010; Cebi, 2018; Genc, 2015; Singh, 2015; Yildirim and Sensoy, 2016; Yildirim, 2018; 2020). The studies have focused over the development of scientific attitudes and alternative ways that can bring scientific attitudes to students (Balaji, 2017; Candrasekaran, 2014; Kucuk and Yildirim, 2020; Smitha, 2012; Sumita, 2017). Among these, informal learning especially field trips outside of 
school promotes a change in learning environment design (Behrent \& Franklin, 2014). For these reasons, studies are supporting the conclusion that some studies whose scope and content are not explained sufficiently increase scientific attitudes as a learning product. On the other hand, studies have been conducted to show that an out-of-school learning experience, whose scope and boundaries are clear, does not differentiate these scientific attitudes in a short time (Kucuk, 2020). The fact that attitudes are effective characteristics and their weak potential to change in a short time leads researchers to study the attitude variable for longer periods. The attitude is expressed as a phenomenon that guides the individual's behavior and causes bias in the decision-making process (Ulgen, 1997). This is why attitudes include the features of how people will behave in different situations. The behavioral feature of the attitude, which has cognitive, affective, and behavioral characteristics, including activating tendencies for certain situations, is especially important. In this respect, scientific attitudes were continued as zone monitoring in the first and second followup after an intervention outside the school in the current research. It is an innovative initiative to continue monitoring persistently to contribute to the literature. In the period coinciding with the second monitoring study, interrupting face-to-face teaching activities in schools due to the Covid-19 epidemic has another importance in terms of examining how scientific attitudes are structured. Although students did not have a formal experience in which they could translate scientific initiative, scientists began to be guests at homes more than ever before. Science has begun to be put into practice every evening in homes, especially for the Covid-19 outbreak (Kucuk, 2021b).

The first thing that should be emphasized in this study is that the first and last follow-up scores of the scientific attitude scale did not change except for the third dimension (Scientific Behavior Display). In other words, it should be emphasized that the scientific attitudes of children in the 1112 age group, who have a five-week out-of-school learning experience specific to the human and environmental unit, do not differ after the intervention or even in the first follow-up (Kucuk, 2020). It may be accepted as a normal situation that the permanence of learning products decreases rather than increases. On the other hand, in the current research, it is a positive situation that scientific attitudes remain stable in all dimensions 
in the first follow-up performed approximately seven and a half months after the first implementation. This can be regarded as an effect of out-ofschool learning when other potentially unmeasurable factors are excluded. In addition, the last follow-up scores made after the first and coinciding with the Covid-19 epidemic period that started in March 2020 are of another importance. The paired sample t-test measurements made for this purpose reveals that there is no statistically significant change in the five sub-scales except one (Scientific Behavior Display).

That is, the scientific attitude scores also remain stable in terms of total scores, although there was a relative increase in several subscales and a relative decrease in others (see table 3). Moreover, the situation in terms of the third subscale is also noteworthy. For these scale scores, a significant difference emerged between the first and last follow-up scores and in favor of the last follow-up. In other words, the scientific behavior displays of students who had science experience out of school increased when they were away from school. At first, although out-of-school science teaching comes to mind as the reason for this, the more logical thing is to just attribute its stability to the intervention applied and naturally seek other reasons for its rise. To deepen this situation, an additional online survey was conducted with the students. These data explicitly refer to topics such as students are following scientists through communication channels regarding Covid-19 vaccine studies as claimed. In this process, students who are aware of the difficulties of the work done, as well as its value for humanity, have increased their scientific behavior display scores. This explains the statistical difference in favor of final follow-up in the relevant subscale of the scientific attitude scale. Supporting this result, students' seeing the difficulty of scientific studies in qualitative data also explains the reason for the partial decrease in the relevant subscale scores (see the sixth factor, Willingness to Conduct Scientific Studies). That is, although students have achieved competence in understanding the nature of scientific work, they are partially unwilling to do this work.

\section{Conclusion}


This research is important to determine the long-term effect of the change in the scientific attitudes of the students who experienced outdoor teaching in science education, also included a panel study on environmental pollution by scientists and field trips carried out specifically for the human and environmental unit and for the environments where scientists are located. However, it is also important in terms of revealing how the scientific attitudes of students are affected by the changing conditions due to the epidemic, as a result of the interruption of face-to-face teaching in schools due to the Covid-19 epidemic that emerged in the last follow-up period. In this respect, although the results of SAI II reveal a statistically significant change in one dimension, due to the stable situation in other dimensions, the result is attributed to the follow-up of the work and speech of scientists in the home environment instead of teaching based on out-of-school learning. In this context, the fact that scientific attitude does not differ statistically despite a partial decrease or increase in the scores of other dimensions is also considered to be a success of out-of-school science teaching. In short, as the Covid-19 epidemic affected every stage of life, it began to shape the scientific attitudes of students as well.

\section{Ethical Issues}

In this study, all rules stated to be followed within the scope of "Higher Education Institutions Scientific Research and Publication Ethics Directive" were followed. None of the actions stated under the title "Actions Against Scientific Research and Publication Ethics", which is the second part of the directive, have been carried out.

Name of the board conducting : Recep Tayyip Erdogan University Sothe ethical review cial Sciences and Humanities Ethics Committee

Date of the ethical assessment : May 5, 2020 decision

Ethics assessment document is- : $\quad 2020 / 33$ sue number 


\section{References}

Afacan, Ö. (2008). İlköğretim öğrencilerinin fen-teknoloji-toplum-çevre (FTTÇ) ilişkisini algllama düzeyleri ve bilimsel tutumlarının tespiti (Kırşehir ili örneği). (Yayımlanmamış Doktora Tezi). Gazi Üniversitesi, Eğitim Bilimleri Enstitüsü, İlköğretim Ana Bilim dalı, Ankara.

Ali, M., Akhtar, N. and Arshad, M. (2019). Investigating the Impact of Field Trips on Secondary School Students' Attitude to Learning of Sciences. Global Social Sciences Review, 4(4), 93-98.

Anderson, D., Lucas, K. and Ginns, I. (2003). Theoretical perspetives on learning in an informal setting. Journal of Research in Science Teaching, 40(2), 177-199.

Andiema, N. C. (2016). Effect of Child Centred Methods on Teaching and Learning of Science Activities in Pre-Schools in Kenya. Journal of Education and Practice, 7(27), 1-9.

Ash, D. (2003). Dialogic inquiry in life science conversations of family groups in a museum. Journal of Research in Science Teaching, 40(2), 138-162.

Bakioğlu, B. (2017). 5. sınıf vücudumuz bilmecesini çözelim ünitesinin okul dışı öğrenme ortamı destekli öğretiminin etkililiği (Yayımlanmamış Doktora Tezi). Amasya Üniversitesi, Fen Bilimleri Enstitüsü, Fen Bilgisi Eğitimi Bilim dalı, Amasya.

Bakioğlu, B. and Karamustafaoğlu, O. (2014). Okul dışı ortamlarda fen eğitimi: diyaliz merkezine teknik bir gezi [Outdoor Science Education: Technical Visit to a Dialysis Center]. Turkish Journal of Teacher Education, 3(2), 15-26.

Balaji, G. (2017). Role of science teacher in developing scientific attitude among secondary school students. Scholarly Research Journal for Interdisciplinary Studies, 4(37). doi:10.21922/srjis.v4i37.10552

Balkan Kıyıcı, F. and Atabek Yiğit, E. (2010). Sınıf duvarlarının ötesinde fen eğitimi: rüzgâr santraline teknik gezi. International Online Journal of Educational Sciences, 2(1), 225-243.

Başaran, İ. E. (1978). Eğitim psikolojisi. Ankara: Bilim Matbaası.

Başdağ, G. (2006). Türkiye'de fen bilgisi eğitiminde okul dışı öğrenme ortamlarına ilişkin yapılan araştırmalar: Bir meta analiz çalı̧̧ması (Yayımlanmamış Yüksek Lisans Tezi). Gazi Üniversitesi, Eğitim Bilimleri Enstitüsü, Fizik Eğitimi Bilim dalı, Ankara. 
Behrent, M. and Franklin, T. (2014). A review of research on school field trips and their value in education. International Journal of Environmental and Science Education, 9(3), 235-245. doi:10.12973/ijese.2014.213a

Binbaşığlu, C. (2000). Okulda ders dışı etkinlikler. Ankara: Milli Eğitim Bakanlığı.

Bingham, A. (1998). Development of problem solving skills in children (Development of Problem Solving Skills in Children). İstanbul: Milli Eğitim Basımevi.

Bou Jaude, S. (2002). Balance of scientific literacy themes in science curricula: the case of Lebanon. International Journal of Science Education, 24(2), 139-156.

Bozdoğan, A. E. (2007). Bilim ve teknoloji müzelerinin fen öğretimindeki yeri ve önemi (Yayımlanmamış Doktora Tezi). Gazi Üniversitesi, Eğitim Bilimleri Enstitüsü, Fen Bilgisi Öğretmenliği Bilim dalı, Ankara.

Bozyılmaz, B. (2005). 4. ve 5. sinıf fen ve teknoloji dersi öğretim programının bilim okur-yazarlı̆̆ı açısından analizi (Yayımlanmamış Yüksek Lisans Tezi). Abant İzzet Baysal Üniversitesi, Sosyal Bilimler Enstitüsü, İlköğretim Fen Bilgisi Eğitimi Ana Bilim dalı, Bolu.

Büyüköztürk, S. (2016). Sosyal bilimler için veri analizi el kitabl, istatistik, araştırma deseni, SPSS uygulamaları ve yorum [Data analysis handbook for social sciences, statistics, research design, SPSS applications and comments]. Ankara: Pegem Publishing.

Bybee, R. W. (1985). The Sisyphean question in science education: What should scientifically and technologically literate person know, value and do-As a citizen? In N. S. Association, Science Technology Society: 1985 Yearbook of the National Science Teachers Association. Washington, DC: National Science Teachers Association.

Bybee, R. W. (1997). Towards an understanding of scientific literacy. In W. Gräber, and C. Bolte, Scientific literacy. An international symposium (p.37-68). Kiel: Institut für die Pädagogik der Naturwissenschaften (IPN).

Can, N. S. (2019). Geri dönüşüm ve çevreye etkileri konusunda okul dışı öğrenme ortamları etkinliklerinin ilkokul öğrencilerinde farklı değişkenler açısından incelenmesi (Yayımlanmamış Yüksek Lisans Tezi). Erzincan Binali Yıldırım Üniversitesi, Sosyal Bilimler Enstitüsü, Sınıf ÖğretmenliğiBilim dalı, Erzincan. 
Candrasekaran, S. (2014). Developing scientific attitude, critical thinking and creative intelligence of higher secondary school biology students by applying synectics techniques. International Journal of Humanities and Social Science Invention, 3(6), 1-8.

Cepni, S., Bacanak, A. and Kucuk, M. (2003). Changing values in the goals of science education: Science-technology-society. Journal of Values Education, 1(4), 7-29.

Chiapetta, E., Sethna, G., and Fillman, D. (1993). Do middle school life science textbooks provide a balance of scientific literacy themes? Journal of Research in Science Teaching, 30(7), 787-797.

Çavuş, R., Öztuna Kaplan, A., Sünbül, F. and Çetin, B. (2010). Okul Dişı Öğrenme ortamlarının öğrencilerin fen ve teknoloji dersine yönelik tutumuna ve motivasyonuna etkisi: Kocaeli Bilim ve Teknoloji Kulübü örneği. IX.Ulusal Fen Bilimleri ve Matematik Eğitimi Kongresi. İzmir: Dokuz Eylül Üniversitesi.

Çebi, H. (2018). Effect of different extracurricular learning environment on students' attitudes and interest in science course. (Unpublished master's thesis). Istanbul: University of Yildiz Teknik.

Çepni, S., Ayvacı, H. Ş. and Bacanak, A. (2004). Fen teknoloji toplum (3 ed.). Trabzon: Celepler Matbaacilik.

DeBoer, G. E. (2000). Scientific literacy: Another look at its historical and contemporary meanings and its relationship to science education reform. Journal of Research in Science Teaching, 37(6), 582-601.

Demirbaş, M. and Yağbasan, R. (2006). Fen bilgisi öğretiminde bilimsel tutumların işlevsel önemi ve bilimsel tutum ölçeğinin Türkçeye uyarlanma çalışması. Uludă̆ Üniversitesi Eğitim Fakültesi Dergisi, 19(2), 271-299.

Dierking, L. D., Falk, J. H., Rennie, L. J., Anderson, D. and Ellenbogen, K. (2003). Policy statement of the "informal science education" ad hoccommittee. Journal of Research in Science Teaching, 40(2), 108-111.

Erentay, N. (2013). Okul dışı doğa uygulamalarının 5. sınıf öğrencilerinin fene ilişkin bilgi, bilimsel süreç becerileri ve çevreye yönelik tutumlarma etkisi (Yayımlanmamış Yüksek Lisans Tezi). Akdeniz Üniverisite, Eğitim Bilimleri Enstitüsü, Eğitim Bilimleri Ana Bilim dalı, Antalya.

Eschenhagen, D., Katmann, U. and Rodi, D. (2008). Fachdidaktik biologie (4 ed.). Koeln: Aulis Verlag Deubner. 
Field, A. (2013). Discovering statistics using IBM SPSS statistics (4 ed.). London: Sage.

Garson, G. D. (2012). Testing statistical assumptions. Asheboro, NC: Statistical Associates.

Genç, M. (2015). The Effect of scientific studies on students' scientific literacy and attitude. OMU J. Fac. Educ, 34(1), 141-152. doi:10.7822/omuefd.34.1.8

Griffin, J. (2004). Research on students and museums: looking more closly at the students in school groups. Science Education, 88(1), 59-70.

Hamurcu, H. (2002). Fen Bilgisi öğretiminde etkili tutumlar. Ĕ̆itim Araştırmaları Dergisi, 8, 144-152.

Hazır, A. and Türkmen, L. (2008). İlköğretim 5. Sınıf öğrencilerinin bilimsel süreç beceri düzeyleri. Selçuk Üniversitesi Ahmet Keleşoğlu Eğitim Fakültesi Dergisi, 26, 81-96.

Higgins, P., Loynes, C. and Crowther, N. (1997). A Guide for Outdoor Educators in Scotland. SNH: Perth.

Hızlıo, A. (2012). Ilköğretim birinci kademe 4. sinıffen ve teknoloji dersinde uygulanan bilimsel süreç becerileri temelli etkinliklerin öğrencilerin fen ve teknoloji özyeterliklerine ve akademik başarılarına etkisi. (Yayımlanmamış Yüksek Lisans Tezi). Niğde Üniversitesi, Eğitim Bilimleri Enstitüsü, İlköğretim Ana Bilim dalı, Niğde.

Hofstein, A. and Rosenfeld, S. (1996). Bridging the gap between formal and informal science learning. Studies in Science Education, 28, 87-112.

Holbrook, J. and Rannikmae, M. (2007). Nature of science education for enhancing scientific literacy. International Journal of Science Education, 29(11), 1347-1362.

Holbrook, J. and Rannikmae, M. (2009). The meaning of scientific literacy. International Journal of Environmental and Science Education, 4(3), 275-288.

Karakaya-Akcadag, C. and Omca-Cobanoglu, E. (2018). Implementation for "human and environment" unit on environmental literacy. Journal of Research in Informal Environments, 3(2), 1-23.

Kelly, J. (2000). Rethinking the elementary science methods course: A case for content, pedagogy, and informal science education. International Journal of Science Education, 22(7), 755-777. doi:10.1080/09500690050044080 
Kilic-Bagci, G., Haymana, F. and Bozyilmaz, B. (2008). Analysis of the elemantary science and technology curriculum of turkey with respect to different aspects of scientific literacy and scientific process. Education and Science, 33, 52-63.

Knapp, D. (2000). Memorable experiences of a science field trip. School Science and Mathematics, 100(2), 65-72.

Koballa Jr, T. R. and Glynn, S. M. (2007). Attitudinal and motivational constructs in science education. In S. K. Abell and N. G. Lederman (Eds.), Handbook of Reseach on Science Education (pp. 75-102). London: Routledge

Kucuk, A. (2020). Fen Bilimleri 5. sını insan ve çevre ünitesinin okul dışı öğrenme ortamlarında öğretimi (Yayımlanmamış Doktora Tezi). Recep Tayyip Erdogan Universitesi, Fen Bilimleri Enstitüsü, Fen Bilgisi Eğitimi Bilim dall, Rize.

Kucuk, A. (2021a). Experiences of Turkish middle school science teachers' first science fair projects coordination. Education Quarterly Reviews, 4(Special Issue 1), 497-512. doi:10.31014/aior.1993.04.02.262

Kucuk, A. (2021b). Ortaokul öğrencilerinin Covid-19 virüsü hakkındaki bilişsel yapılarının incelenmesi. 4. Ulusal Fen Bilimleri ve Matematik Eğitimi Kongresi. Burdur: Burdur Mehmet Akif Ersoy Üniversitesi.

Küçük, A. and Yıldırım, N. (2020). The effect of out-of-school learning activities on 5th grade students' science, technology, society and environment views. Turkish Journal of Teacher Education, 9(1), 37-63.

Küçük, M. (2006). Bilimin doğasın ilköğretim 7. sını öğrencilerine öğretmeye yönelik bir çalışma (Yayımlanmamış Doktora Tezi). Karadeniz Teknik Üniversitesi, Fen Bilimleri Enstitüsü, İlköğretim Ana Bilim dalı, Trabzon.

Küçük, M. and Bağ, H. (2018). 4 ve 5. sınıf öğrencilerinin bilim insanı imajlarının karşılaştırılması. Bayburt Üniversitesi Ĕ̆itim Fakültesi Dergisi, 7(2), 125-138.

Lederman, N. and Niess, M. (1998). Survival of the fittest. School Science and Mathematics, 98(4), 169-172.

Lin, P. Y. and Schunn, C. D. (2016). The dimensions and impact of informal science learning experiences on middle schoolers' attitudes and abilities in science. International Journal of Science Education, 38(17), 25512572. doi:10.1080/09500693.2016.1251631 
Martin, L. M. (2004). An emerging research framework for studying informal learning and schools. Science Education, 88, 71-82.

MEB. (2005). Illköğretim Fen ve Teknoloji Dersi Öğretim Programı. Ankara: Milli Eğitim Bakanlı̆̆1.

MEB. (2018). Fen bilimleri dersi öğretim programı (İlkokul ve Ortaokul 3,4,5,6,7 ve 8. Sinıflar). Ankara: Milli Eğitim Bakanlığı.

Moore, W. R. and Foy, R. (1997). The scientific attitude inventory: A revision(SAI II). Journal of Research in Science Teaching, 34(4), 327-336.

OECD. (2017). PISA 2015 assessment and analytical framework: science, reading, mathematic, fnancial literacy and collaborative problem solving. Paris: OECD Publishing. doi:10.1787/9789264281820

Ozturk, A. (2014). The effects of curricula at Mevlana Public and Science Center on students' science process skills and attitudes toward science (Unpublished master's thesis). Izmir: Ege University.

Patton, M. Q. (2018). Nitel Araştırma ve Değerlendirme Yöntemleri (2 ed.). (B. Mesut, and D. S. Beşir, Trans.) Ankara: Pegem Akademi.

Pella, M. O., O'Hearn, G. T., and Gale, C. G. (1966). Referents to scientific literacy. Journal of Research in Science Teaching(4), 199-208.

Pitaf, A. I., and Farooq, M. (2012). Measurement of scientifc attitude of secondary school students in Pakistan. Academic Research International, 2(2), 379-392.

Prokop, P., Tuncer, G., and Kvasnicak, R. (2007). Short-term effects of field programme on students' knowledge and attitude toward biology: A Slovak Experience. Journal of Science Education and Technology, 16(3), 247-255. doi:10.1007/s10956-007-9044-8

Rickinson, M., Dillon, J., Teamey, K., Morris, M., Choi, M. Y., Sanders, D. and Benefield, P. (2004). A review of research on outdoor learning. Preston Montford, Shropshire: Field Studies Council.

Salmi, H. S. (1993). Science centre education: Motivation and learning in informal education (Unpublished Master Thesis). Helsinki: University of Helsinki.

Simpson, R. D., Koballa Jr, T. R., Oliver, J. S. and Crawley, F. E. (1994). Research on effective dimension of science learning. In D. L. Gabel, Handbook of Research in Science Teaching and Learning . Macmillan Publishing Company. 
Singh, M. (2015). A week long summer program does make a difference: A strategy of increasing underrepresented minorit y students' interest in science. European Journal of Health and Biology Education, 4(2), 21-30.

Smitha, V. P. (2012). Inquiry training model and guided discovery learning for fostering critical thinking and scientific attitude. Kozhikode: Vilavath Publications.

Soysal, E. (2019). Okul dışı öğrenme ortamlarının ortaokul 7. sınıf öğrencilerinin fen bilimleri dersine yönelik ilgi, tutum ve motivasyonlarna etkisi. (Yayımlanmamış Yüksek Lisans Tezi). Gazi Üniversitesi, Eğitim Bilimleri Enstitüsü, Matematik ve Fen Bilimleri Eğitimi Ana Bilim dall, Ankara.

Sumita, S. S. (2017). A Study of scientific attitude development of junior college student through various activities in the junior college (Unpublished doctoral thesis). Rajasthan: Shri Jagdishprasad Jhabarmal Tibarewala University.

Taş, E. and Gülen, S. (2019). Analysis of the influence of outdoor education activities on seventh grade students. Participatory Educational Research (PER), 6(2), 122-143. doi:10.17275/per.19.17.6.2

Tezel, Ö. and Tezgören, I. (2019). Investigation of the relationship between scientific literacy levels and problem solving skills of eighth grade students. ESTUDAM Journal of Education, 4(2), 68-84.

Ülgen, G. (1997). Eğitim psikolojisi. Ankara: Alkım Yayınevi.

Yildırım, H. (2018). The impact of out-of-school learning environments on 6th grade secondary school students attitude towards science course. Journal of Education and Training Studies, 6(12), 24-41.

Ylldırım, H. (2020). the effect of using out-of-school learning environments in science teaching on motivation for learning science. Participatory Educational Research, 7(1), 143-161. doi:10.17275/per.20.9.7.1

Yıldırım, H. İ. and Şensoy, Ö. (2016). Bilim şenliklerinin 6. sınıf öğrencilerinin fen bilimleri dersine yönelik tutumlarına etkisi. Türk Ĕ̆itim Bilimleri Dergisi, 14(1), 23-40.

\section{Kaynakça Bilgisi / Citation Information}

Küçük, A. (2021). Investigation of the change towards scientific attitudes of students with out-of-school learning experience. OPUS-International Journal of Society Studies, 18(44), 7552-7580. DOI: 10.26466/opus. 933305. 